\title{
Index of Authors
}

Abe, M., Shibui, H., Iriki, T. and Kumeno, F. Relation between diet and protozoal population in the rumen 197

Adams, J. F., McEwan, F. and Wilson, A. The vitamin $B_{12}$ content of meals and items of diet 65

AdDY, H. A. see CERNY, K. 105

Agarwal, K. N., see Gupta, M. I 5 I

Alfaro, B. and Heatox, F. W. Relationships between copper, zinc and iron in the plasma, soft tissues and skeleton of the rat during $\mathrm{Cu}$ deficiency 73

Allison, R. M., Laird, W. M. and Synge, R. L. M. Notes on a deamination method proposed for determining "chemically available lysine' of proteins $5 \mathbf{I}$

Andrieux-Domont, $C$, and Le Van Hung. Effects of magnesium deficiency on reproduction in the white rat 203

AsHidA, K. see Horie, Y. 23

Ashworth, A., Milner, P. F., Waterlow, J. C. and WaLker, R. B. Absorption of iron from maize (Zea mays L.) and soya beans (Glycine hispida Max.) in Jamaican infants 269

Baker, B. A. see LunN, P. G. 399

Balch, C. C. see Bines, J. A. 457

Bines, J. A. and BALCH, C. C. Relative retentions of the nitrogen of urea and groundnut in isoenergetic diets for growing heifers 457

Birch, G. G., Etheridge, I. J. and Green, L. F. Short-term effects of feeding rats with glucose syrup fractions and dextrose 87

Braude, R. and Newport, M. J. Artificial rearing of pigs. 4. The replacement of butterfat in a whole-milk diet by either beef tallow, coconut oil or soya-bean oil 447

Breckenridge, G. see Czerkawski, J. W. 317

Bremner, I. and Dalgarno, A. C. Iron metabolism in the veal calf. The availability of different iron compounds 229

Burnett, J. see Evans, E. W. 357

Buttle, H. L. see Ternouj'H, J. H. 387

Cameron, R. D. see Luick, J. R. 245

Cawson, R. A. see Greney, T. H. 221

Cerný, K. and AdDy, H. A. The winged bean (Psophocarpus palustris Desv.) in the treatment of kwashiorkor IO5

Contes, M. E. see Hewitt, D. 423

Coor, G. C. Increased glycine absorption rate associated with acute bacterial infections in $\operatorname{man} 377$

Crawford, M. A. see Sinclair, A. J. I 27

Cymbaluk, N. F., Gordon, A. J. and the late NEUdoERFFER, T. S. The effect of the chemical composition of maize plant lignin on the digestibility of maize stalk in the rumen of cattle I
Czerkawsie, J. W. and Breckenridge, G. Dissimilation of $1,2-$ propanediol by rumen microorganisms 317

Dalgarno, A. C. see Bremner, I. 229

Eskeland, B., Pfander, W. H. and Preston, R. L. Utilization of volatile fatty acids and glucose for protein deposition in lambs 347

ETHERIDGe, I. J. see BirCh, G. G. 87

Evans, E. W., Pearce, G. R., Burnett, J. and Pillinger, S. L. Changes in some physical characteristics of the digesta in the reticulorumen of cows fed once daily 357

Evarts, R. P. and Oksanen, A. Phospholipids in artificially induced dystrophy of calves 293

Fellenius, E., Nisbeth, U., Pilström, L. and KIESSLING, K.-H. Changes in the activity of citrate lyase, malic enzyme and acetyl-CoA synthetase in rat liver after short-term and long-term feeding with ethanol 307

Fellentus, E. see also Pilström, L. 297

Frood, J. D. L. see Rutishauser, I. H. E. $26 \mathrm{I}$

Gordon, A. J. see Cymbaluk, N. F. I

Green, L. F. see Birch, G. G. 87

Grenby, 'T. H., Paterson, F. M. and Cawson, R. A. Dental caries and plaque formation from diets containing sucrose or glucose in gnotobiotic rats infected with Streptococcus strain IB-I 600221

Grovum, W. L. and Williams, V. J. Rate of passage of digesta in sheep. I. The effect of level of food intake on marker retention times along the small intestine and on apparent water absorption in the small and large intestines $\mathrm{I}_{3}$

Gupta, M. and Agarwal, K. N. Free amino acid patterns of plasma, erythrocytes and leucocytes in hypoproteinaemia $\mathbf{I}_{5} \mathrm{I}$

Hall, G. A. and Howell, J. MCC. Lesions produced by copper deficiency in neonate and older rats 95

Hay, R. W. see LUnN, P. G. 399

IIeaton, F. W. see Alfaro, B. 73

Hegazi, S. M. see Salem, S. I. 113

Hewit', D., Coates, M. E., Kakade, M. L. and LiENER, I. E. A comparison of fractions prepared from navy (haricot) beans (Phaseolus vulgaris L.) in diets for germ-free and conventional chicks 423

Horie, Y. and ASHIDA, K. Effect of an adequateprotein diet after a low-protein diet on protein catabolism in growing rats 23

Howeld, J. MCC. see Hall, G. A. 95 
Hussain, M. A. A fresh look at the incidence of protcin deficiency in Pakistan $2 \mathbf{I I}$

IRIKI, T. see ABE, M, I97

Jubson, G. I. and LeNg, R. A. Studies on the control of gluconeogenesis in sheep: effect of glucose infusion 159

JtDson, G. J. and LENG, R. A. Studies on the control of gluconeogenesis in sheep: effect of propionate, casein and butyrate infusions 175

Kakade, M. L. see Hewitt, D. 423

Kiessling, K.-H. see Fellenius, E. 307

Kiessling, K.-H. see Pilström, L. 297

Kumeno, F. see Abe, M. I97

LaIRD, W. M. see Allison, R. M. $5 \mathrm{I}$

LENG, R. A. see JUDSON, G. J. I 59, I 75

LE VAN Hung, see ANDRIEUX-Domont, C. 203

LIENER, I. E. see HEWIT' D. 423

Luick, J. R., Person, S. J., Cameron, R. D. and White, R. G. Seasonal variations in glucose metabolism of reindeer (Rangifer tarandus L.) estimated with $\left[\mathrm{U}_{-}{ }^{11} \mathrm{C}\right] \mathrm{glucose}$ and $\left[3^{-} \mathrm{H}\right]-$ glucose 245

LinN, P. G., Whitehead, R. G., Hay, R. W. and Baker, B. A. Progressive changes in serum cortisol, insulin and growth hormone concentrations and their relationship to the distorted amino acid pattern during the development of kwashiorkor 399

MCAllan, A. B. and Smith, R. H. Degradation of nucleic acids in the rumen $33 \mathrm{I}$

McAllaN, A. B. and Smith, R. H. Degradation of nucleic acid derivatives by rumen bacteria in vitro 467

MCEwan, F. see Adams, J. F. 65

Milner, P. F. see Ashworth, A. 269

Moncos, S. R. see Salem, S. I. I I 3

Neudoerffer, T. S. see Crmbaluk, N. F. I

Newport, M. J. see Braude, R. 447

Nisbeth, U. see Fellenius, E. 307

Nitzan, Z. see Volcani, R. I $2 \mathrm{r}$

Oksanen, A. see Evarts, R. P. 293

Owen, E. C. see West, D. W. 33,43

Paterson, F. M. see Grendy, 'T. H. 221

Pearce, G. R. see Evans, E. W. 357

Person, S. J. see Luick, J. R. 245

Pfander, W. H. see Eskeland, B. 347

Pillinger, S. L. see Evans, E. W. 357

Pilström, L., Fellenius, E. and Kiessiang, K.-H. The use of a semi-synthetic liquid diet for the supply of ethanol to rats and its effect on lysosomal enzyme activities in the liver 297

Pilström, L. see also Feldenius, E. 307

Preston, R. L. see Eskei.and, B. 347
Rowlands, G. J. see Twardock, A. R. 437

Rutishauser, I. H. E. and Frood, J. D. L. The effect of a traditional low-fat diet on energy and protein intake, serum albumin concentration and body-weight in Ugandan preschool children $26 \mathrm{I}$

Salem, S. I, Hegazi, S. M. and Morcos, S. R. Experimental protein-energy deficiency in rats. Ratio of serine +glycine to threonine as an index of deficiency I 3

Sansom, B. F, see Twardock, A. R. 437

Shibui, H. see ABe, M. 197

Sinclair, A. I. and Crawford, M. A. The effect of a low-fat maternal diet on neonatal rats 127

SILAN, D. see Volcani, R. I2I

Smith, R. H. see McAllan, A. B. 33I, 467

Sprat, G. H. see Williams, D. L. 57

Symonds, H. W. see Twardock, A. R. 437

Synge, R. L. M. see Allison, R. M. 5 I

Ternouty, J. H. and Buttee, H. L. Concurrent studies on the flow of digesta in the duodenum and of exocrine pancreatic secretion of calves. The collection of the exocrine pancreatic secretion from a duodenal cannula 387

Turner, M. R. Perinatal mortality, growth and survival to weaning in offspring of rats reared on diets moderately deficient in protein 139

Twardock, A. R., Symonds, H. W., Saysom, B. F. and Rowlands, G. J. The effect of litter size upon foetal growth rate and the placental transfer of calcium and phosphorus in superovulated Scottish half-bred ewes 437

Volcani, R., Zisling, R., Sklan, D. and Nitzan, Z. The composition of chinchilla milk I2I

Walker, R. B. see Ashworth, A. 269

WATERlow, J. C. see AshWorth, A. 269

Webster, A.J.F. and White, F. Portal blood flow and heat production in the digestive tract of sheep 279

WEST, D. W, and OwEN, E. C. Degradation of riboflavin by alimentary bacteria of the ruminant and man: production of 7,8-dimethyl-10carboxymethylisoalloxazine 33

WeSt, D. W. and OWen, E. C. Metabolism of riboflavin: reduction of 7,8-dimethyl-10-formylmethylisoalloxazine by an enzyme in liver 43

White, F. see Wrbster, A. J. F. 279

White, R. G. see Luick, J. R. 245

Whitehead, R. G. see LUNN, P. G. 399

Williams, D. L. and Spray, G. H. The effects of diets containing raw soya-bean flour on the vitamin $B_{12}$ status of rats 57

Williams, V. J. see Grovum, W. L. I3

Wilson, A. see Adams, J. F. 65

ZISLING, R. see VolCANI, R. I2I 